\title{
大気中負棒対平板ギャップの直流フラッシ オーバ過程
}

$\begin{array}{lllll}\text { 正員 常 安 } & \text { 啺 } & \text { (福岡大) } \\ \text { 正員 生 澤 泰 二 } & \text { (福岡大) } \\ \text { 正員 西 嶋 喜代人 } & \text { (福岡大) } \\ \text { 正員 渡 辺 健 二 } & \text { (九州電力) }\end{array}$

\section{1. まえがき}

近年, 直流送電の長所が認識され，関連技術の進歩 ああって，世界に打りる設備容量住 $30,000 \mathrm{MW}$ に達 しようとしている。我が国においても直流 $\pm 250 \mathrm{kV}$ 送電線が完成し，次期送電圧として $\pm 500 \mathrm{kV}$ が検討 されており，その絶縁設計には直流放電現象の解明が 不可欠である。また，放電現象の研究においては，電 圧の変化が極めて緩やかな直流電圧印加時の現象が最 あ基本的なあのと考えられ，物理的にも興味をもたれ てきた。このような理由から数多くの研究がなされ報 告されてきた。しかし不平等電界を形成するギャップ については，コロナの形態と形成機構，之の開始電 圧拈よびフラッシオーバ電圧などに関するものが多 く(1)ー(5)，フラッシオーバ直前の状況に関する報告は 少ない。これは, 印加電压の変化が緩やかで, フラッ シオーバ時刻の変動幅が極めて広いため, その直前の 状況を観測することが困難であるからであるう。ま た，インパルス電圧印加時の観測結果から，高電界側 電極が陰極のときの方が現象は複雑であると推測され $ろ^{(6) \sim(8)}$ 。従って，乙のようなギャップのフラッシオ 一バ過程に関しては鈴木らの観測のほかはほとんど報 告されていないようである(9)ー(11)。

そこで筆者らは，直径が $2 \mathrm{~cm}$ の半球棒対平板ギャ ップに負極性直流電圧を印加したときのコロナとフラ

DC Breakdown Processes of Negative Rod to Plane Gaps in Atmospheric Air, By Itaru Tsuneyasu, Member, Yasuji Izawa, Member, Kiyoto Nisijima, Member (Faculty of Engineering, Fukuoka University), \& Kenji Watanabe, Member (Kyusyu Electric Power Co. Inc).

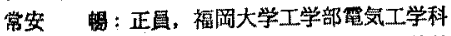

生㴆 泰二: 正員, 福成大学工学部電気工学科

西嶋点代人：正員，褔岡大学工学部笔気工学科

洨辺 煡二: 正貝, 九州電力 (株)
ッシオーバ状況をイメージコンバータカメラなどを用 いて観測し検討した。その結果，第 1 コロナはグロー 状コロナであるが，後続コロナは次第に径が細くなっ てストリーマコロナに遷移するてとおよびフラッシオ 一バ過程としては基本的には 3 種類の過程があるとと などを明らかにした。本論文では，これらについて観 測結果を例示しフラッシオーバ過程の概念図を提示し て述べる。

\section{2. 実験装置と方法}

先端が半球状で直径 $\phi$ が $2 \mathrm{~cm}$ の黄銅棒電極之直径 $50 \mathrm{~cm}$ の銅平円板電極を対向させた棒対平板ギャップ をギャップ軸が任ば鉛直になるように大気中におい た。図1に示すように平板電極付抵抗 $r_{1}, r_{2}$ を経て 接地し, 棒電極はマイクロメータヘッドに取り付け, ギャップの長さ $d$ は $0.2 \sim 7 \mathrm{~cm}$ の範囲で変化した。 このギャップに直流高電圧発生装置（ニチコン DCG $100 \mathrm{~K} 10 \mathrm{~B})$ の発生直流負電圧を $0.1 \mu \mathrm{F}$ の並列コン デンサ $C$ 之直列抵抗 $R s$ 柿よびインピーダンス $Z$ を経て盯加した。電王の調整は手動で行い，コロナ開 始予想值の約 $80 \%$ までは $1 \mathrm{kV} / \mathrm{s}$ 程度の速度で上昇 し, その後は $0.05 \mathrm{kV} / \mathrm{s}$ 程度の速度で極めて紘やか に上昇した。またコロナ開始後更に電圧の上昇を要す るときは $0.2 \mathrm{kV} / \mathrm{s}$ 程度で上昇しフラッシオーバ電 王の予想值付近では再び $0.05 \mathrm{kV} / \mathrm{s}$ 程度で上昇した。 コロナ開始電圧, フラッシオーバ電圧などの値として はそれぞれ10回の測定值の平均值をとった。

放電状況はイメージコンバータカメラ (ICC), イメ ージインテンシファイヤ (II) および静止カメラを適宜 組合せて観測するとともに直接肉眼であ観測した。ま たギャップ全体を視野とする光電子増倍管 PM1 のは 


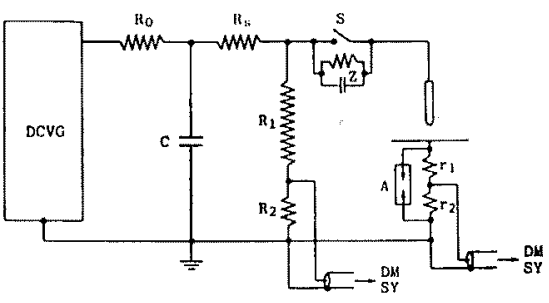

(a) 実猎可路图

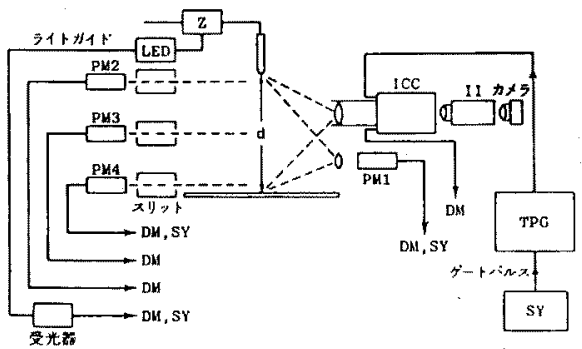

(b) 钼淇采绕因

$\mathrm{R}_{s}=0 \sim 4 \mathrm{k} \Omega, \quad r_{1}=r_{z}=200 \Omega, C=0.1 \mu \mathrm{F}$

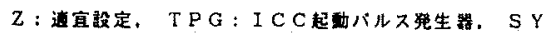
: シンクロスコーフ， DM:デシタルメモリ，LED：

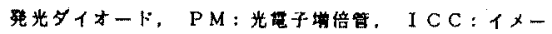
シコンバータカメラ. I I：イメージインテンシファイア

図 1 実験装置図

Fig. 1. Schematic diagram of experimental setup, also indicating triggering sequence.

かに, ギャップ軸で視野の上下幅が約 $0.2 \mathrm{~cm}$ でその 中心がそれぞれ棒笔極先端近傍、ギャップ中央付近お よび平板電極近傍にある 3 個の光電子增倍管（上から PM 2, PM 3, PM 4) を使用した。ICC 始動用パルス 発生器 (TPG) の起動には，適宜 $r_{2}$ あるいは $Z$ の端 子電圧, PM 1, PM 4 の出力などによって始動したシ ンクロスコープ SY のゲートパルスを用いた。また，

電流; 光電子增倍管出力, ICC のモニターパルスなど の波形はディジタルメモリー（岩通 DM 902）によっ て観測した。

$Z$ は抵抗とコンデンサを並列に接続したすので，常 時は短絡しておき，ごく限られた現象の写真観測時に だけ使用した。その際, 静電容量と抵抗は必要に応じ 適当に調整した。Rs の值は小さすぎると前回までの フラッシオーバによる放電痕のため測定值の変動䒇が 大きくなり，大きすぎるこロナ電流が扣制され，現

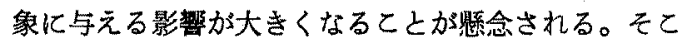
でRsの值はギャップの長さ $d$ が $3 \mathrm{~cm}$ 以下では零之 し， $d$ の増加とともに最大 $4 \mathrm{k} \Omega$ まで増加した。この 間 $R s=0$ のときの測定值と比較し，差異のないとと を確加め。

ギャップは水銀灯（東芝理化学用水銀ランプ SHL100 UV-2) で紫外線を照射した。测定值はすべて炤
射時の值である。ICCによる観測香照射のあとで行っ たが，放電に伴う発光のほかに電極表面などにおける 照射光の反射も観測されるので，両者を識別するため に非照射時の钼測す行った。しかしフラッシオーバ過 程には照射の有無の影鎧は認められなかった。

奏験は広い空間の開放大気中で行ったので湿度の制 御はしなかったが，相対湿度は50〜60\%であった。

\section{3. 実験結果と考察}

〈3.1〉，放㫣特性 最初に発生進展するコロナす

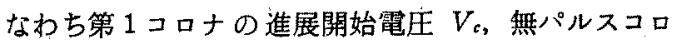

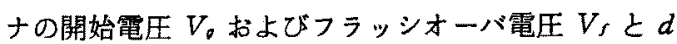
との関係は図 2 に示すようになる。本論文では， $V_{f}=$ $V_{c}$ なる領域， $V_{f}>V_{c}$ で無パルスコロナが認められ ない領域および $V_{f}>V_{o}>V_{c}$ なる領域をそれぞれ $C$ 領域， $B$ 領域および $A$ 領域と呼ふととにする。

$d \leqq 2 \mathrm{~cm}$ では, 第 1 コナ発生後フラッシオーバま での時間 $t r$ は図 3 (a)に示すようになる。すなわち， $d$ を $1.0 \mathrm{~cm}$ 加ら $1.3 \mathrm{~cm}$ まで增すと $t$ ， $0.3 \mu \mathrm{s}$ 程 度から $5 \mu \mathrm{s}$ 程度まで增加する。しかし $d=1.4 \mathrm{~cm}$ て は第 1 コロナ開始後 $1.5 \mu \mathrm{s}$ 程度で第 2 パルスが発生 して $t_{s}$ は $1.8 \mu \mathrm{s}$ 程度になり， $d=1.2 \mathrm{~cm}$ のとさより 加えって小さくなる。なお，この第 2 パルスは後述す るように陽極側からの正コロナの進展に起因する。d を $1.4 \mathrm{~cm}$ 加ら增すと $t_{f}$ は増加し， $1.65 \mathrm{~cm}$ では第 2 パルス発生後短時間でフラッシオーバする場合およ び第 2 パルスは発生せず t。 が $50 \sim 130 \mu \mathrm{s}$ 程度の場合 と $360 \mu \mathrm{s}$ 程度の場合とがある。上記の第 2 グループ の值は $d \leqq 1.2 \mathrm{~cm}$ におりる $t_{r}-d$ 曲線の延長上にあ ると見なせる。 $d$ を更に増すと $t$ は上記第 3 のグル ープの值だけになり， $d$ が $2 \mathrm{~cm}$ のときの $700 \mu \mathrm{s}$ 程

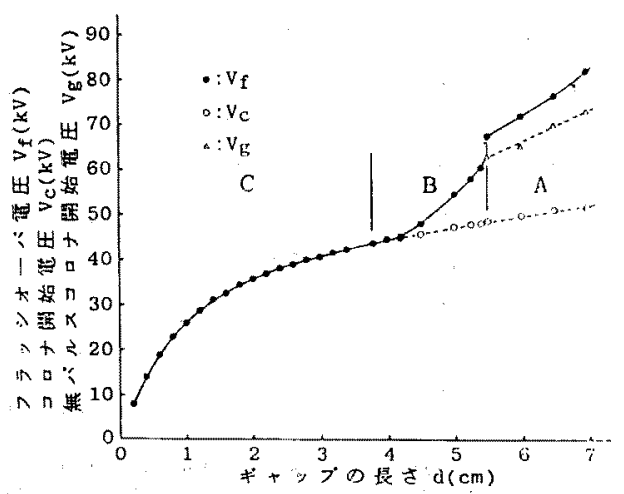

困 $2 V_{c}, V_{\theta}, V_{f}$ 亡 $d$ टの関係

Fig. 2. First corona inception voltage $V_{c}$, pulseless corona inception voltage $V_{\theta}$ and fiashover voltage $V_{f}$ vs gap length $d$. 


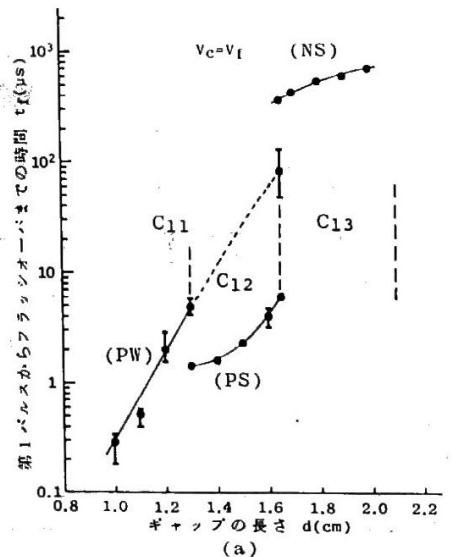

(a)

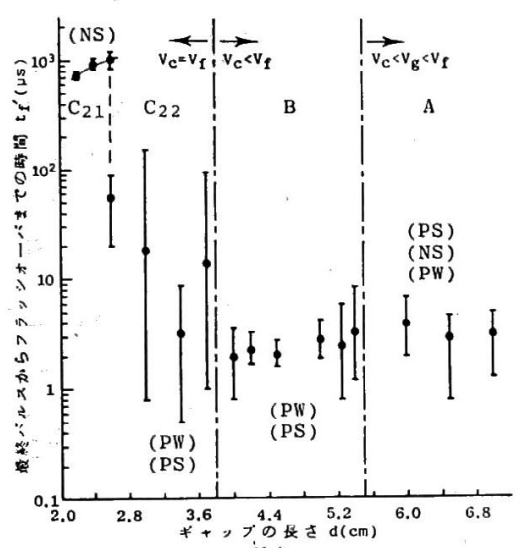

(b)

図 $3 t_{f}, t_{f}^{\prime}$ と $d$ との関係

Fig. 3. Time required for flashover $t_{s}$ after the lst corona start and $t_{f}{ }^{\prime}$ after the final corona start vs gap length.

度まで $d$ の増加ととあに增す。このように $d$ の值に よって $t_{f}-d$ 特性が異なるので, $d<1.65 \mathrm{~cm}$ を $C_{11}$ 領 域, $1.65 \leqq d \leqq 2.0 \mathrm{~cm}$ を $C_{13}$ 領域, $1.3 \leqq d \leqq 1.65 \mathrm{~cm}$ を $C_{12}$ 領域とする。すなわち, この場合は $C_{11}$ 領域 中に $C_{12}$ 領域が介在する。なお $\phi \leqq 0.5 \mathrm{~cm}$ の場合は $C_{12}$ 領域は認められなかった。

$C$ 領域でも $d>2 \mathrm{~cm}$ では後続負コロナが進展し， その発生回数が $d$ の増加之ともに増し, 発生時刻は 大きく変動し， $t_{s}$ は更に大幅に変動するので, $t_{f}$ の 測定はほとんど無意味になる。そこでこの領域では, フラッシオーバとその直前の負コロナ（以下最終コロ ナと呼ぶ)の発生との時間間隔 $t s^{\prime}$ を湘定した。その結 果, 図 3 (b)に示すように, $t_{f}^{\prime}$ は $d$ が $2.0 \mathrm{~cm}$ のと きの $700 \mu \mathrm{s}$ 程度加ら $2.6 \mathrm{~cm}$ のときの $1,000 \mu \mathrm{s}$ 程度 まで，dの增加ととあに增し，乙の範囲における $t_{f}{ }^{\prime}$ $d$ 曲線は $C_{13}$ 領域におりる $t s-d$ 曲線〔図 3 (a)〕の 延長上にあるとみなせる。しかし $d>2.8 \mathrm{~cm}$ では $t_{s}^{\prime}$ は $200 \mu \mathrm{s}$ 程度以下の值だけになる。このように, $C$ 領域で後続負コロナが進展してフラッシオーバする領 域には $t_{f}^{\prime}-d$ 特性が異なる二つの領域があるので, こ れらをそれぞれ $C_{21}$ 領域および $C_{22}$ 領域とする〔図 3 (b)]。

$d$ が $3.8 \mathrm{~cm}$ 以上になると $B$ 領域に入り, $t_{s}^{\prime}$ は 10

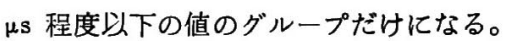

$A$ 領域 $(d \geqq 5.5 \mathrm{~cm})$ になると, $t_{f}^{\prime}$ は $B$ 領域之同 様に $10 \mu \mathrm{s}$ 程度以下の場合が多い。但し $d$ が $A$ 領域 における下限值付近では無パルスコロナから直接フラ ッシオーバする場合があり，てのときの $t_{f}{ }^{\prime}$ の測定は 無意味である。また, 短時間定在する過渡的な無パル スコロナからフラッシオーバし，104 $\mathrm{s}$ 程度あるいは それ以上の值の $t_{\boldsymbol{s}}{ }^{\prime}$ が測定される場合ああるが, 図 3 (b) にはこのような場合の $t_{s}^{\prime}$ の值は示していな w。

〈3・2〉 負コロナの形覘 $A$ 領域において肉眼で 観測される負コロナは，印加電圧 $V$ が $V$ 。程度の之 きはグローコロナであるが、Vを上昇するとストリー マコロナになる。従ってパルス性の負コロナには 2 種 類の形態があることになる。

図 4 は $d$ が $3 \mathrm{~cm}$ のとき (C22 領域) の観測例で, 同図 (a) は第 1 コロナの進展直前から第 5 コロナの進 展までの間の流し写真, (b)は第 5 コロナから第 8 コ ロナまでを含む静止写真である。これらからわかるよ うに，第 1 コナは回転だ円体状のグローコロナであ るが，V が不变であるにもかかわらず, 後続コロナ は後に進展するすのほど径が細く, 進展距離が長くな り，第 3 以降のコロナはストリーマ状になる〔図4 (a))。また各コロナの幹部は同一経路をとる〔図 4 (b))。これに伴って電流パルスの波高值は第 1 コロ ナの $7 \mathrm{~mA}$ 程度から第 5 コロナの 20 25 $\mathrm{mA}$ 程度ま で増加し, 最終コロナでは 25〜 $50 \mathrm{~mA}$ 程度になる。 なお，第 1 コロナ進展後第 5 コロナまで連続的に進展 したものと仮定したときの進展速度は $2 \times 10^{3} \mathrm{~cm} / \mathrm{s}$ 程

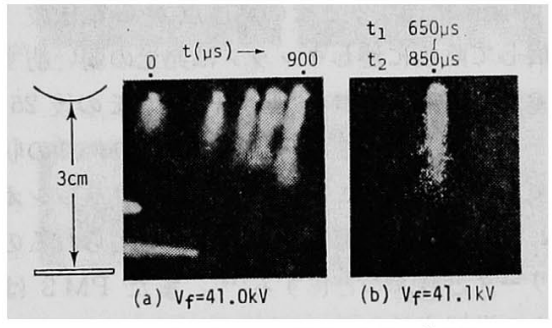

(a) streak picture, (b) static picture.

.図 4 負コロナの進展

Fig. 4. Image converter photos of negative corona. 
度であった。

$A$ 領域では, $V=V_{c}$ の之きのコロナは発生時間間 隔が極めて長く, 後続コロナあグロー状コロナであ る。これは休止時間中に先行コロナの空間電荷が十分 に減少するためと考えられる。Vを上昇すると、コロ ナの発生間隔が短くなり, 棒電極先端表面におりるそ れらの発生起点が周縁部に移動し, 多くの起点からコ ロナが発生進展するようになる。同一起点からも， $C_{22}$ 領域における之同様にコロナが間欠的に発生し, 同一 幹部を経て進展する。 $V \fallingdotseq V$ 。 で棒電極先端の中心付 近から無パルスコロナが発生し定在するようになる と，その空間電荷効果によって周縁部からのコロナの 発生が抑制される。更に $V$ を上昇すると， $V<V$ 。の ときよりも電極表面の更に周縁部からコロナが進展し て無パルスコロナの定在を阻止する。しかし短時間定 在する過渡的な無パルスコロナは発生しし, $V$ が $V f に$ 近いときは，棒電極先端中央部からストリーマコロナ とは異なる細く滑らかな形状のチャネルが進展するこ とがある。とれは上記の過渡的無パルスコロナの幹部 が進展したあのである。

〈3.3〉 フラッシオーバ過程 $t_{f}, t_{f}^{\prime}-d$ 特性は> ラッシォーバ過程と密接な関係があると考えられる。 本節では，前述の各領域におけるフラッシオーバ過程 を観測例をあげて説明する。観測写真に示した時間 $t$ は最終コロナ（第 1 コロナのみのときは第 1 コロナ） の発生時間を $t=0$ とした。こま撮り写真各こまの露 光開始と停止時間はそれぞれ $t_{1}, t_{2}$ とし, こま撮り写 真であるととの表示とした。

(1) $C_{11}$ 領域 $d$ が $C_{11}$ 領域における上限値に 近いときの観測例を図 5 (a) （c）に示す。（a )は流 し写真と ICC のモニターパルス (MP) および電流の オシログラム, (b)はこま撮り写真, ( c ) は PM2, PM 4 出力のオシログラムである。この場合は, 第 1 コロ ナは途中で急速な進展を停止するが, その負空間電荷 群は弱い発光を保ちながら陽極に向かう。この発光域 (LZ) が陽極に達するとその到達点から電圧波 (PW) が進展して陰極に達しギャップは発光の弱い紡すい状 のチャネルで橋絡される $\{$ 図 5 (b) $\}$ 。その後 $25 \mu \mathrm{s}$ 程 度でチャネルの陽極端から収縮が始まり，この収縮部 (PL) の伸長ととあに電流が増加してフラッシオーバ する。従って PL は導電性が高いと考えられるのでこ れをリーダと呼ぶととにする(13)。また PM 2 は第 1 コロナの進展直前から, PM 4 は LZ の陽極到達時 からフラッシオーバまで発光を検知している〔図 5 (c))。なお，第1コロナ進展後フラッシオーバまで の間の電流の極小值は約 $0.5 \mathrm{~mA}$ であった。以下, 上

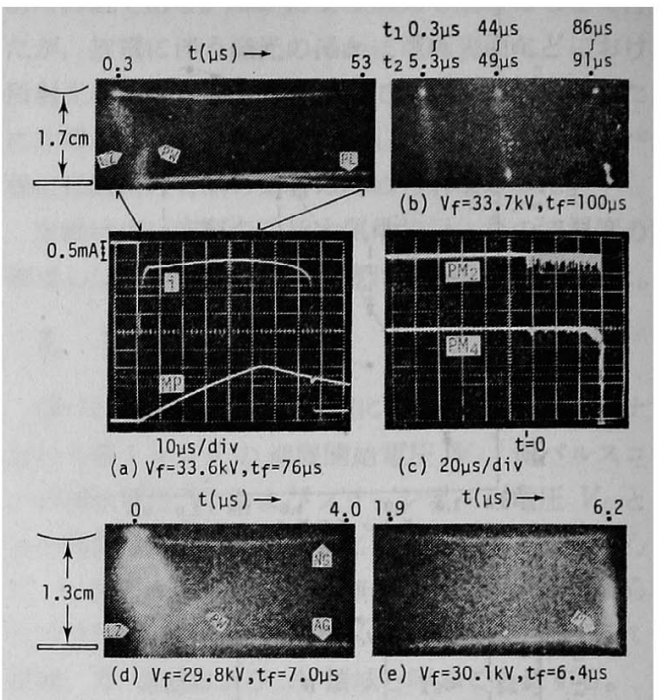

図 5 観測写真とオシログラム ( $C_{11}$ 領域 $)$

Fig. 5. Image converter photos of prebreakdown phenomena and oscillograms ( $C_{11}$ region).

述のようなフラッシオーバ過程を PW 過程とする。

図 $5(\mathrm{~d}),(\mathrm{e})$ は $d=1.3 \mathrm{~cm}$ のときの観測例であ る。このときの第 1 コロは陽極に到達して PW を 進展させ, 電流が增加してフラッシオーバする。フラ ッシオーバ直前におけるリーダ PL の進展距離と $d$ との比は $d \fallingdotseq 1.7 \mathrm{~cm}$ のとさよりあ小さく, $d$ の値を 更に減少するとリーダは認められなくなる。従って $d$ が大でギャップの平均電界 $V_{s} / d$ が低いほどフラッシ オーバに要するリーダの進展距離が長くなる。

（2） $C_{12}$ 領域 観測例を困 6 亿示す。同図(a) は第 1 コロナ進展直前からフラッシオーバの約 $0.3 \mu \mathrm{s}$ 前までの間の流し写真と, このときの電流オシログラ ム，(b)は（a)にみられる第 2 パルス発生直前からフ ラッシオーバ直前までの流し写真, (c) は第 2 パルス 発生時の高速度の流し写真である。との場合も第 $1 \sqsupset$ ロナがギャップ中間で進展を停止した後陽極に向かっ た発光域 LZによって電圧波 $\mathrm{PW}$ が進展し,てれが LZ の上端に達するとその点から一次正ストリーマ pps を進展させる。とのときその起点から強い発光波 LW が陰極之陽極方向へ進展する。前者は pps よりあ著 しく低い速度で進展し, pps チャネルの発光を強くか つ持続的にするので，てれを二次正ストリーマ sps と呼ぶことにする(12)。また，LW は，LZ の発光を格 段に強くかつ持続的にし，陽極に到達すると反転して 陰極へ向加，sps の頭部に達してその速度を高め る。図6(b)にみられるように, pps の進展によって 陰極近傍にあ発光が持続的なチャネルが形成される場 
合があるが，乙れは第 1 コロナ進展後にこの部分に集 積された負荷間電荷群中を pps が進展したためであ ると考えられる。このようにして，正ストリーマ起点 の下部の比較的に径の大きいチャネルと, 正ストリー マによって形成されたチャネルの発光は著しく強く, かつ持続的になり，てれがギャップを橋絡してフラッ シオーバする。pps 発生後フラッシオーバに至る間の 電流の最低值は $40 \mathrm{~mA}$ 程度で, 正ストリーマの進展 後チャネルの導電性が急増することがわかる。上述の フラッシオーバ過程を PS 過程と呼ぶことにする。

(3) $C_{13}$ 領域 $d$ が $1.8 \mathrm{~cm}$ のときの観測例を 図 7 亿示す。同図 (a ) は現象の前半, (b) は後半の流 し写真，(c)，(d)はそれぞれ時間的にほほ（a ), (b) に対応するこま撮り写真である。このときの $V_{f} / d$ は 約 $19 \mathrm{kV} / \mathrm{cm}$ で，第 1 コロナが急速な進展を停止する 位置々陽極間の距離は $d$ の増加とともに增す。第 1 コロナによる負空間電荷群の陽極到達時に発生する電 圧波 PW は, 途中で正ストリーマを進展させるとと

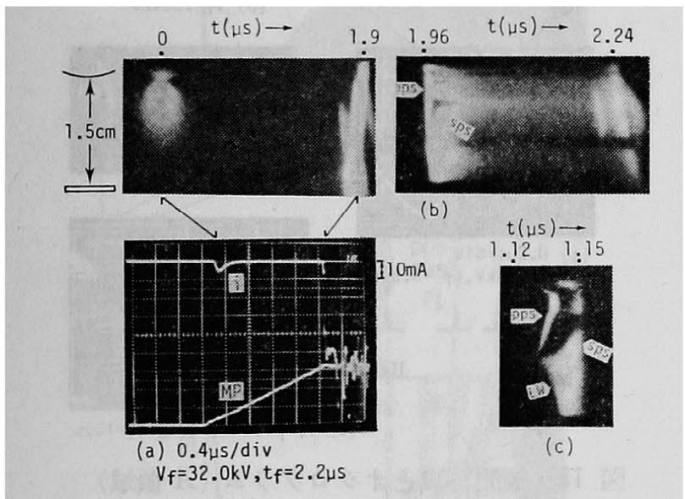

図 6 観測写真とオシログラム $\left(C_{12}\right.$ 領域 $)$

Fig. 6. Image converter photos of prebreakdown phenomena and oscillogram ( $C_{12}$ region).

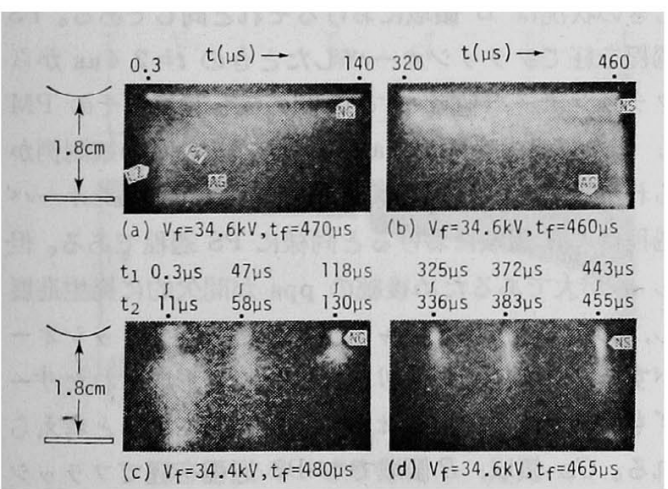

図 7 観測写真とオシログラム $\left(C_{13}\right.$ 領域 $)$

Fig. 7. Image converter photos of prebreakdown phenomena ( $C_{13}$ region).
なくギャップ中間で速度を急速に減少し，陰極近傍に 達する。例えば，図 7 (a)の例では，ギャップ中間か ら陰極までの約 $0.8 \mathrm{~cm}$ を進展するのに $50 \mu \mathrm{s}$ 程度を 要している。第1コロナ進展後, 陰極先端に負グロー と考えられる強い発光域 NG が見られ，PW の起点 には陽極グローと考えられる発光域 $A G$ が形成され る。本例では AG は第 1 コロナ進展後 $100 \mu \mathrm{s}$ 程度で 消滅しているが，ての間はギャップ全長にわたって弱 い発光域か認められ，その後は院極近傍に無パルスコ ロナ状の発光域のみが認められるようになる(図 7 (b)，(d) )。因 7 の例では, 電流は第 1 コロナ進展後 $100 \mu \mathrm{s}$ 程度で極小となり, $350 \mu \mathrm{s}$ 程度で再び増加し始 める。この頃から無パルスコロナ状発光域の幹部 NS が次第に伸長し， $t$ が $400 \mu \mathrm{s}$ 程度でギャップは NS とその下方の太いグロー状チャネルによって橋絡され

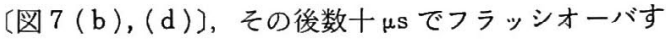
る。上述のようなフラッシオーバ過程を NS 過程と 名付ける。

（4） $C_{21}$ 領域図8(a), (b)はd が $2.1 \mathrm{~cm}$ のときのこま撮り写真である。第 1 コロナ進展後電流 はほとんど零まで減衰するが, 最終コロナ進展後は $0.18 \mathrm{~mA}$ 程度まで減衰した後, 再び増加してフラッ シオーバし, 最終コロナ発生後のフラッシオーバ過程 は明らかに前述の NS 過程である。図8(c)は $d=$ $2.8 \mathrm{~cm}\left(C_{21}\right.$ 領域と $C_{22}$ 領域との境界付近 $)$ での流し 写真之 MP および電流のオシログラムである。この 場合は最終コロナが $d$ の $3 / 4$ 程度進展し, PW の進 展後陽極グロー AG が形成されるがやがて消滅し， NS が伸長してフラッシォーバしている。最終コロナ はストリーマコロナであるため図 8 (b)の場合よりあ NS が細くなっている。最終コロナの進展距離が $d$ の $2 / 3$ 程度以下のときは AG の形成か認めら行，

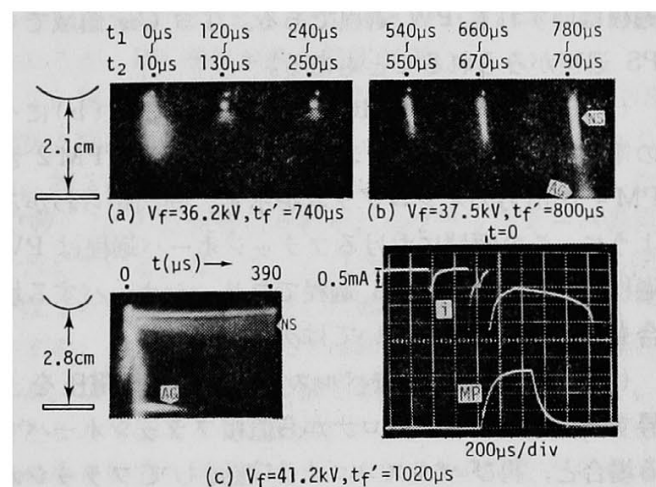

図 8 観測写真とオシログラム $\left(C_{21}\right.$ 領域)

Fig. 8. Image converter photos of prebreakdown phenomena and oscillogram $\left(C_{21}\right.$ region). 


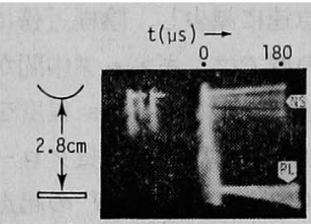

(a) $V_{f}=41.2 k V, t_{f}^{\prime}=220 \mu \mathrm{s}$ $t=0$

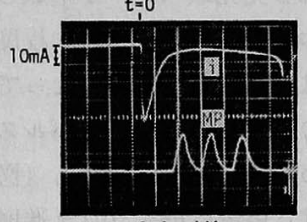

$0.4 \mu \mathrm{s} / \mathrm{div}$

(c) $V_{f}=41,2 k V, t_{f}^{\prime}=2.5 \mu$

図 9 観測写真とオシログラム $\left(C_{22}\right.$ 領域 $)$

Fig. 9. Image converter photos of prebreakdown phenomena and oscillogram ( $C_{22}$ region).

$t_{f^{\prime}}$ は $1,000 \mu \mathrm{s}$ を超す。

(5) $C_{22}$ 領域 との領域では $t_{f}^{\prime}$ は $200 \mu \mathrm{s}$ 程 度から $1 \mu \mathrm{s}$ 以下の値まで大幅に変動する。図9(a) は $t_{f^{\prime}}$ が $220 \mu \mathrm{s}$ のときの流し写真である。この場合は 陽極近傍まで進展した最終コロナによる負空間電荷群 が $\mathrm{PW}$ を進展させ，その後正リーダ PL が進展し， 一方，NS も進展してフラッシオーバしている。図 9 (b) は $t_{f^{\prime}}$ が $5.5 \mu \mathrm{s}$ のときの流し写真，（c）はこま 撮り写真とその電流および MP のオシログラムであ る。この場合は最終コロナ進展後 $\mathrm{PW}$ がコロナチャ ネルの発光を強めながら陰極に到達し, その直後にフ ラッシオーバしている。図9(b)ではチャネルの下半 部がリーダ化していると思われる。前述のように，負 ストリーマは同一経路を繰返し進展し，しかも径が細 いため，PW の進展によって容易に導電性が高めら れ， $t_{f}{ }^{\prime}$ が小さくなるあのと考えられる。

これらの場合の最終コロナ進展後のフラッシオーバ 過程はいずれむ $\mathrm{PW}$ 過程である。なお $C_{22}$ 領域であ PS 過程がみられるととむある。

(6) B 領域 図10（a）に流し写真，(b)にそ の電流と MP 出力のオシログラム, (c)に PM 2 と PM 4 の出力のオシログラムを示ず。同図からわかる ように，この領域におけるフラッシオーバ過程は $\mathrm{PW}$ 過程である。なお, PS 過程でフラッシオーバする場 合ああるが，これについては次項で述べる。

（7） $A$ 領域 無パルスコロナ発生後電圧を上 昇すると，無パルスコロナから直接フラッシオーバす る場合と, 再びパルスコロナが進展してフラッシオ 一バする場合がある。後の場合は最終コロナ進展後 PW, PS, NS 過程のいずれかを経てフラッシオーバ する。このうち PW 過程を経てフラッシオーバする

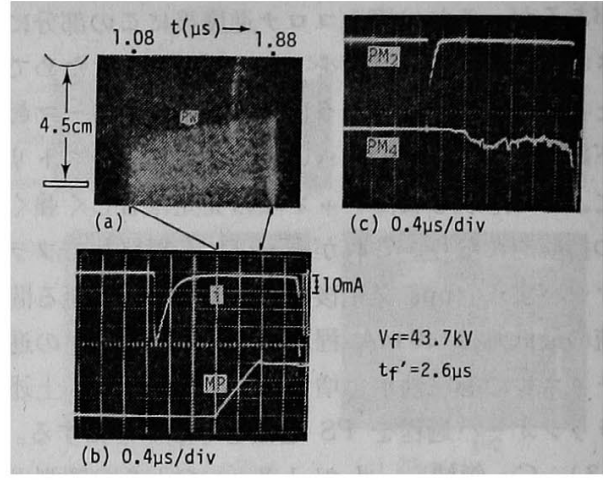

図 10 観测写真とオシログラム $(B$ 領域) Fig. 10. Image converter photos of prebreakdown phenomena and oscillograms ( $B$ region).

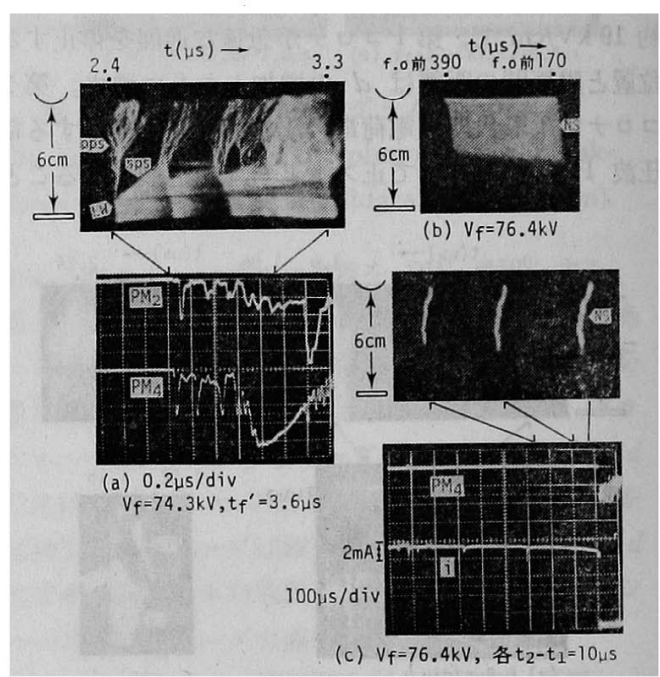

図 11 観測写真とオシログラム（ $A$ 領域）

Fig. 11. Image converter photos of prebreakdown phenomena and oscillograms ( $A$ region).

ときの状況は $B$ 領域におけるそれと同じである。PS 過程を経てフラッシオーバしたときの $t \fallingdotseq 2.4 \mu \mathrm{s}$ 加 フラッシオーバ直前までの間の流し写真とその PM 2, PM 4 出力を図 11 (a ) に示す。これらの観測例か らわかるように, 最終コロナ進展後のフラッシオーバ 過程は $C_{12}$ 領域におけると同様に PS 過程である。但 し $d$ が大であるため後続の pps が間欠的に発生進展 し，sps も進展してギャップを橋絡し，フラッシオー バする。この間正ストリーマの起点に形成されたリー ダあ伸長してフラッシオーバに寄与していると考えら れる。 $C_{22}$ 領域, $B$ 領域でも PS 過程を経てフラッシ オーバする場合があるが， $d$ が小なるほど正ストリー マの発生回数が少なくなる。図11(b)，(c) は NS 過程でフラッシオーバしたときの観测例で,（b)は流 
し写真，(c)はこま撮り写真およびそのときの PM 4 の出力と電流のオシログラムである。同図から最終コ ロナ進展後その幹部 NS が持続的な発光を保ち, てれ が次第に進展してギャップの半ば程度に達すると， NS と陽極間にやや径の大きいチャネルの発光と陽極 グローが観測されるようになり，その直後にフラッシ オーバする。とのときの $t_{s}{ }^{\prime}$ は $2,000 \mu \mathrm{s}$ 以上にあな り極めて大きい。（c）にみられる電流パルスはNSの 起点とは別の個所から進展したコロナによるあのであ る。また，無パルスコロナから直接フラッシオーバす る場合は，その幹部が次第に伸長し，上述と同様な状 況を示す。

〈3.4〉放電特性 とフラッシオーバ過程フラッ シオーバ過程には図 12 に示すように次の 3 種類の過 程があるととがわかった。すなわち，

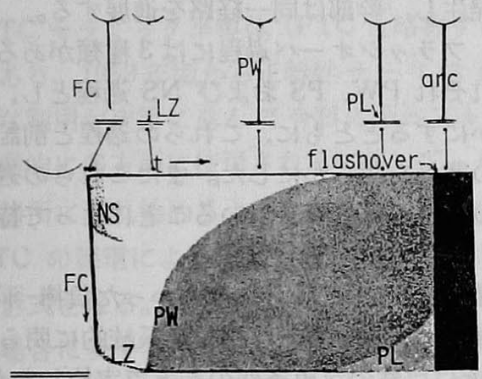

(a) PW Process

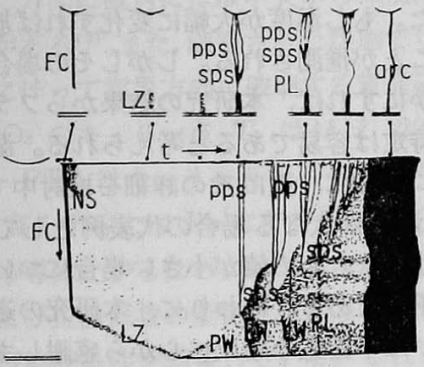

(b) PS Process
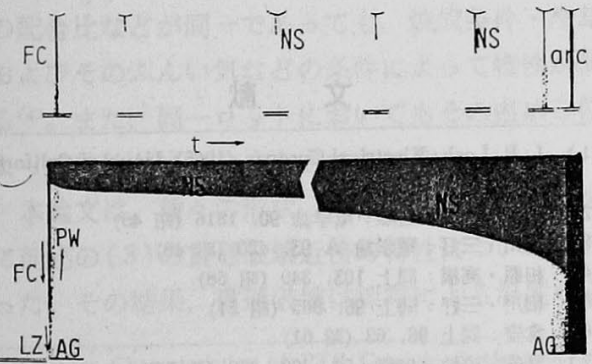

(c) NS Process

上：流し掫り粎式 下：こま拫り様式

FC: 第一あるいは最終コロナ

図 12 フラッシオーバ過程の想定図

Fig. 12. Conceptual figures of flashover processes.
表 1 領域とフラッシオーバ過程

Table 1. Flashover processes in each of seven regions.

\begin{tabular}{|c|c|c|c|c|c|c|c|}
\hline V & \multicolumn{5}{|c|}{$V_{c}=V_{f}$} & $V_{c}<V_{f}<V_{\theta}$ & $V_{c}<V_{\theta}<V_{f}$ \\
\hline 䫗 域 & $C_{11}$ & $C_{12}$ & $C_{13}$ & $C_{21}$ & $C_{\mathbf{n}}$ & $B$ & A \\
\hline 過 程 & PW & PS & NS & NS & $\begin{array}{c}\% \mathrm{PW} \\
\mathrm{PS}\end{array}$ & $\begin{array}{c}\text { ※PW } \\
\text { PS }\end{array}$ & $\begin{array}{r}\mathrm{PW} \\
\text { \%S } \\
\mathrm{NS}\end{array}$ \\
\hline 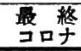 & & グロー & מי & & - & リ & ーマコロナ \\
\hline
\end{tabular}

（a） PW 過程 負コロナあるいはその負空間 電荷群の陽極到達点から進展した $\mathrm{PW}$ によってギャ ップを橋絡するチャネルが形成され，その導電性が增 してフラッシオーバする。この間にリーダが進展する 場合はまず正リーダが進展する。

（b） PS 過程 PW が進展途中で正ストリーマ を進展させ，てれによってフラッシオーバが起てる。 $d$ の值が大なるときは後続の正ストリーマの間欠的 な発生回数が増す。

(c) NS 過程 負コロナの幹部 NS が $2 \times 10^{3}$ $\mathrm{cm} / \mathrm{s}$ 程度の低い速度で伸長し, ギャップを橋絡して フラッシオーバする。

$t_{f}, t_{f^{\prime}}-d$ 特性とフラッシオーバ過程との間には密 接な関係があり, $t_{f}, t_{f}{ }^{\prime}-d$ 特性から分類した 7 つの 領域におけるフラッシオーバ過程は表 1 亿示すように なる。すなわち,

(1) $C_{11} ， C_{12}$ および $C_{13}$ 領域ではそれぞれ $\mathrm{PW}$, PS および NS 過程を経てフラッシオーバする。

(2) $C_{21}$ 領域では最終コロナ進展後 NS 過程を経 てフラッシオーバする。

(3) $C_{22}$ 領域では最終コロナ進展後 $\mathrm{PW}$ 過程を経 てフラッシオーバすることが多いが PS 過程もみられ る。

(4) $B$ 領域では PW 過程あるいは PS 過程を経て フラッシオーバする。

(5) $A$ 領域では PW，PS，NS のいずれの過程もみ られるが, PS 過程が最も頻度が高い。

また無パルスコロナの幹部が低速度で伸長し，NS 過程と同様の過程を経てフラッシオーバするとともあ る。図 3 の各領域における $t_{f}, t_{f}{ }^{\prime}-d$ 曲線に付記した (PW) などの記号はそれぞれのフラッシオーバ過程 を示している。従って，てれら各領域の境界付近を除 けば 100\% それぞれに示した過程を経てフラッシオー バする。また，境界付近では隣接両領域の過程が混在 する。なお表 1 の※印は最も頻度が高い過程を示す。

ところで図 2 で $A$ 領域における $V_{q}-d$ 曲線を $d$ の 值の小さい方へ延長すると, $d$ が $2 \mathrm{~cm}$ 程度で $C$ 領域 の $V_{\boldsymbol{f}}-d$ 曲線之接近する。過渡的な無パルスコロナは $V_{0}$ より若干低い電圧で出現し始めるととを考慮する と, $C_{13}, C_{21}$ 領域では NS 過程を経てフラッシオーバ 


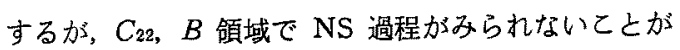
説明できる。すなおち $C_{22}$ 領域では NS 過程でのフ ラッシオーバの条件が満たされないため, 更に後続の コロナが進展して陽極あるいはその近傍に達し，PW あるいは PS 過程を経てフラッシオーバすると考えら れる。また $d$ の值が大きくなると，負コロナの陽極 近傍到達には $V$ 上 上り高い電压が必要になり， $B$ 領域 に入る。 $B$ 領域で $d$ が増すと $V S$ が上昇し，その值が $V_{0}$ 程度になると無パルスコロナが出現して $A$ 領域 に入る。従って $A$ 領域では 3 種類の過程のいずれも が見られるが，dの值が大なるほど目コロナの陽極到 達が困難になって PW 過程の発生頻度は減少する。 例えば $C_{22}$ 領域では PW 過程の発生確率は $80 \%$ 程 度であるが， $d$ が $6 \mathrm{~cm}$ ( $A$ 領域) では $5 \%$ 程度に低 下する。なお，上に述べたような理由から $B$ 領域は $V_{c}<V_{s}<V_{q}$ なる領域と考えてよい。実際 $B$ 領域で 紫外線照射を止めて急速传電圧を上昇すると照射時の $V_{f}$ より高い電任で無パルスコロナが出現し，フラッ シオ一バ電圧が異常に高くなることがある。

上述の各過程に対応して PM 2 PM 4 の出力波形 は特徴的な相互関係を示す。例えば，因 5 (c), 図10 (c) ( PW 過程), 因 11 (a) (PS 過程), 図 11(c) (NS 過程)などである。従って, 3 個の光電子増倍管 の出力之電流のオシログラムからフラッシオーバ過程 を特定できる。

〈3.5〉 インパルス印加時との比較 雷インパル ス印加時には後続のコロナが先行コロナの頭部から発 生するステップ状の進展がみられる。これは畉加電压 波頭における電圧の急峻な上昇による ${ }^{(7)}$ 。従って電圧 の変化が極めて楥やかな直流印加時にはこのような現 象はみられない。前述 (〈3・2〉節) の直流印加時のス テップ状進展では各コロナは除極から進展し, 発生時 間間䧣は $100 \mu \mathrm{s}$ 以上であり，後続コロナは正負空間 電荷のドリフトによる陰極近傍の電界の回復によって 発生すると考えられる。

また，雷インパルス印加時には值流印加時の $\mathrm{PW}$ および PS 過程がみられるが, フラッシオーバまでに 長時間を要する NS 過程はみられない(7)。

\section{4. まとめ}

本研究では, 負棒一平板ギャップの直流フラッシオー バ過程を観測検討した結果を述べた。コロナ開始電 生, 無パルスコロナ出現電圧, フラッシオーバ電圧を $V_{c}, V_{g}, V_{f}$ とし $V_{c}=V_{f}, V_{c}<V_{s}<V_{g}, V_{c}<V_{g}<$ $V$, なる領域をそれぞれ $C, B, A$ 領域とした。結果 を要約すると以下のようになる。

（1）負コロナとしては第1コロナの進展だけでフ

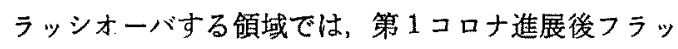
シオーバまでの時間とギャップの長さ $d$ との関係が $C_{11}, C_{12}, C_{13}$ の三つの領域で互い《異なる。
(2) C 領域で後続目コロナの進展後にフラッシオ 一バする領域では, 最終コロナ進展後フラッシオーバ までの時間と $d$ との関係が $C_{21}$ 領域と $C_{22}$ 領域とで 異なる。

（3） $d>1.3 \mathrm{~cm}$ では，第 1 コナは回転だ円体状 のグローコロナである。しかし $C_{21} ， C_{22}$ 領域におけ る後続の負コロナは後に発生するすのほど径が紐く, 進展距離が長くなり，第 3 あるいは第 4 コロナ以降は ストリーマコロナになる。ストリーマコロナの幹部は いずれあ先行コロナと同一経路をとる。

(4) $A$ 領域では, $V=V c$ のときのコロナの発生 時間間隔は極めて長く, 後続コロナもグローコロナで ある。しかし $V$ を上昇すると, 前項と同様にストリ ーマコロナが進展するようになり，それらの起点は棒 電極先端の周縁部に広加る。各起点からは間欠的にコ ロナが発生し，幹部は同一経路を進展する。

（5）フラッシオーバ過程には 3 種類がある。これ らをそれぞれ PW, PS および NS 過程とし, 各過程 を明ら汃化するとしに，これらの過程と前記 7 つの 領域上の関係を明ら加にした。またてれらの過程仙 2 〜3 個の光電子增倍管を用いるととによって特定でき る。

以上,従来ほとんど明らかでなかった負棒-平板ギャ ップの直流フラッシオーバ過程を系統的に明らかにし た。本研究仿自然の気象条件のむとで実施したが，実験 中の湿度の変動幅は相対湿度が $50 \sim 60 \%$ で比較的に 小であった。すし湿度が大幅に変化すれば放電特性す 変化するととが推測される。しかしその場合す放電特 性を明らか江すれば，本研究の結果からフラッシオー バ過程の特定は容易であると考えられる。湿度の及汇 す影響については，更にその詳細を検討中である( ${ }^{(3)}$ 。 本論文では $\phi$ が大なる場合の代表例として $\phi=2 \mathrm{~cm}$ について述へた。 $\phi$ の値が小さい場合についても後日 報告する予定である。終わりに，本研究の遂行に御協 力いただいた卒論生の諸氏に心から感謝します。

(昭和 62 年 8 月 31 日受付, 同年 12 月 7 日再受付)

\section{文献}

(1) L. B. Loeb : Electrical Coronas (1965) Univ, of California Press

（2）生田・牛田·石黑: 電学誌 90,1816 (昭 45)

(3) 細川·三好: 電学諭 A 93,420 (昭 48)

(4) 相原 ·高標: 同上 103,349(绍 58)

(5) 緗川·三好: 同上 96,365 (明 51)

(6) 常安: 同上 96、63 (昭 51)

（7）常安·㮫崎・赤崎: 同上 98，373 (晒 53)

（8）常安·赤崎: 同上 93,487 (昭 48)

(9) 鈴木.三宅・原：放電研究 No.79(明 55)

(10) 近藤・梶田・三好: 電学猃A 95，17 (昭 50)

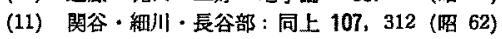

(12) G. G. Hudson \& L. B. Loeb: Phys. Rev. 123, 29 (1961)

(13) 江島·生摆・常安・西嶋: 昭 62 電気関係学会九州支部連大 No. 412 